\title{
PERLINDUNGAN MEREK BAGI PEMEGANG HAK MEREK DITINJAU DARI UNDANG-UNDANG NOMOR 15 TAHUN 2001 TENTANG MEREK
}

\author{
DIAN NOVITA \\ Fakultas Hukum, Universitas Wiraraja Sumenep \\ dianovita79@yahoo.co.id
}

\begin{abstract}
ABSTRAK
Merek adalah tanda yang berupa gambar, nama, kata, huruf, angkaangka, susunan warna, atau kombinasi dari unsur-unsur tersebut yang memiliki daya pembeda dan digunakan dalam kegiatan perdagangan barang atau jasa. Agar setiap produsen atau pengusaha atau pedagang mempunyai jaminan perlindungan hukum terhadap hak atas merek barang dagangannya, Undang-undang Nomor 15 Tahun 2001 tentang Merek mewajibkan merek tersebut didaftarkan. Dengan terdaftarnya merek sebagaimana dimaksud dalam Pasal 3 Undang-undang tersebut, barulah pemegang merek akan diakui atas kepemilikan merek produk dagangannya. Hal ini sesuai dengan prinsip yang dianut oleh Undang-undang Merek Indonesia, yakni first to file principle, bukan first come, first out principle. Berdasarkan prinsip tersebut, maka seseorang yang ingin memiliki hak atas merek harus melakukan pendaftaran atas merek yang bersangkutan.
\end{abstract}

Kata Kunci : Perlindungan Bagi Pemegang Hak Merek.

\section{A. PENDAHULUAN}

Merek berfungsi sebagai tanda pengenal untuk membedakan hasil produksi yang dihasilkan seseorang atau beberapa orang secara bersama-sama atau badan hukum dengan produksi orang lain atau badan hukum lainnya sebagai alat promosi sehingga dalam mempromosikan hasil produksinya cukup dengan menyebut mereknya sebagai jaminan atas mutu barangnya menunjukkan asal barang atau jasa yang dihasilkan.

Objek atas merek adalah karya-karya seseorang yang berupa tanda, baik tulisan, gambar, kombinasi tulisan dan gambar yang diciptakan dengan tujuan untuk membedakan barang yang satu dengan yang lain tetapi yang sejenis.

Setiap merek menampilkan wujud reputasi yang bernilai moral, material, dan komersial. Reputasi yang melekat pada merek merupakan suatu bentuk hak milik. Reputasi dalam dunia usaha yang dipandang sebagai kunci bagi sukses atau tidaknya suatu bisnis, dimana banyak pengusaha yang berlomba-lomba untuk memupuk ataupun menjaga reputasinya dengan menjaga kualitas produk dan memberikan pelayanan.

Bagi para pedagang atau pengusaha, merek merupakan salah satu media untuk memperoleh reputasi baik dan kepercayaan dari konsumen. Selain itu, perusahaan pencetus merek tersebut dapat membangun hubungan antara reputasi tersebut dengan merek yang telah dipakai oleh perusahaan tersebut. Apabila suatu produk tidak memiliki merek, tentu produk tersebut tidak akan dikenal oleh konsumen. 
Hal ini tentu tidak memberikan keuntungan bagi pihak perusahaan. Merek baik secara langsung maupun tidak langsung mewakili kualitas, imej, atau reputasi suatu produk. Oleh karena itu, merek mempunyai posisi penting bagi berkembangnya usaha atau bisnis para pedagang atau pengusaha yang terbaik bagi konsumen.Merek adalah sesuatu (gambar atau nama) yang dapat digunakan untuk mengidentifikasi suatu produk barang atau jasa yang ada di dalam pasaran.

Melalui merek, masyarakat sebagai konsumen akan dengan mudah mengenali suatu produk perusahaan tertentu. Merek biasanya dicantumkan pada barang atau pada kemasan atau bungkusan barang yang dijual atau dicantumkan secara tertentu pada hal-hal yang terkait dengan jasa yang dijual.

Kemudian, Undang-undang Nomor 21 Tahun 1961 tentang Merek tersebut diganti dengan Undang-undang Nomor 19 Tahun 1992 tentang Merek sebagaimana telah diubah dengan Undang-undang Nomor 14 Tahun 1997 tentang Perubahan atas Undang-undang Nomor 19 Tahun 1992 tentang Merek.

Hukum merek berfungsi melindungi pemilik merek tersebut dari pihak lain yang hendak mengambil keuntungan dengan cara tidak jujur. Dengan adanya Undang-undang Nomor 15 Tahun 2001 tentang merek diharapkan dapat memenuhi kebutuhan para pedagang atau pengusaha atas adanya perlindungan terhadap hak kekayaan intelektual (dalam hal ini merek) untuk memproduksi barang atau jasa sebagai komoditi dagang.

Saat ini Indonesia telah mempunyai Undang-undang Merek terbaru yaitu Undangundang Nomor 15 Tahun 2001 yang diundangkan pada tanggal 1 Agustus 2001 seiring dengan telah diratifikasinya Konvensi Pembentukan World Trade Organization (WTO). Undang-undang ini menggantikan Undang-undang Nomor 19 Tahun 1992 tentang Merek sebagaimana telah diubah dengan Undang undang Nomor 14 Tahun 1997 tentang Perubahan atas Undang-undang Nomor 19 Tahun 1992 tentang Merek.

Setelah Undang-undang tersebut berlaku, pemerintah pun segera melakukan tindakan pembenahan dalam setiap hal yang berkaitan dengan merek. Hal ini untuk memberikan pelayanan bagi para pengusaha atau pedagang agar dalam mengembangkan usahanya, mereka memperoleh perlindungan hukum atas tenaga, pikiran, waktu dan biaya yang telah mereka korbankan dalam rangka membangun suatu reputasi perusahaan dalam wujud merek.

Dalam konteks negara Indonesia, perlindungan hukum di bidang-bidang HAKI yang telah di atur dalam hukum Indonesia meliputi:

Rahasia Dagang (Undang-undang Nomor 30 Tahun 2000, Desain Industri (Undangundang Nomor 31 Tahun 2000), Hak Paten (Undang-undang Nomor 14 Tahun 2001), Hak Merek ( Undang-undang Nomor 15 Tahun 2001), Hak Cipta (Undang-undang Nomor 19 
Tahun 2002), (Undang-undang HAKI, Tahun 2004.

Setelah Undang-undang tersebut berlaku, pemerintah pun segera melakukan tindakan pembenahan dalam setiap hal yang berkaitan dengan merek. Hal ini untuk memberikan pelayanan bagi para pengusaha atau pedagang agar dalam mengembangkan usahanya, mereka memperoleh perlindungan hukum atas tenaga, pikiran, waktu dan biaya yang telah mereka korbankan dalam rangka membangun suatu reputasi perusahaan dalam wujud merek.

Adanya pengaturan tentang merek diharapkan dapat mencegah terjadinya persaingan usaha tidak sehat. Dengan merek, produk barang atau jasa sejenis dapat dibedakan asal muasalnya, kualitasnya, serta keterjaminan bahwa produk itu original.

Hal ini tertuang dalam konsiderans Undang-undang Nomor 15 Tahun 2001 tentang Merek bagian menimbang butir a yang berbunyi "bahwa di dalam era perdagangan global, sejalan dengan konvensikonvensi internasional yang telah diratifikasi Indonesia, peranan Merek menjadi sangat penting, terutama dalam menjaga persaingan usaha yang sehat"

Berbeda dengan hak cipta, merek harus didaftarkan terlebih dahulu di dalam Daftar Umum Merek. Agar setiap produsen atau pengusaha atau pedagang mempunyai jaminan perlindungan hukum terhadap hak atas merek barang dagangannya, Undang-undang Nomor 15 Tahun 2001 tentang Merek mewajibkan merek tersebut didaftarkan. Dengan terdaftarnya merek sebagaimana dimaksud dalam Pasal 3 Undang-undang tersebut, barulah pemegang merek akan diakui atas kepemilikan merek produk dagangannya. Hal ini sesuai dengan prinsip yang dianut oleh Undang-undang Merek Indonesia, yakni. Pertama untuk mangajukan, bukan dating pertama, kelur datang prinsip. Berdasarkan prinsip tersebut, maka seseorang yang ingin memiliki hak atas merek harus melakukan pendaftaran atas merek yang bersangkutan.

Ada beberapa faktor yang melatar belakangi para pedagang atau pengusaha tersebut mendaftarkan merek atas produknya sesuai dengan ketentuan hukum yang berlaku. Demikian pula beberapa faktor yang menghambat para pedagang atau pengusaha tersebut mendaftarkan merek atas produknya sesuai dengan ketentuan hukum yang berlaku.

Merek sangat penting baik dalam dunia periklanan dan pemasaran. Oleh karena itu, maka suatu produk yang dipasarkan akan lebih mudah dikenal oleh konsumen bila dilekati dengan suatu merek yang merupakan ciri dari produk yang dijual tersebut. Selain itu, apabila produsen barang tersebut ingin agar merek yang diciptakannya terhindar dari pihak lain yang berperilaku curang terhadap merek dagangannya, maka merek tersebut harus didaftarkan dalam Daftar Umum Merek. Dengan terdaftarnya suatu merek dalam Daftar Umum Merek, maka pemilik merek akan memperoleh hak atas merek yang bersifat ekslusif dari negara. 


\section{B. PEMBAHASAN}

Merek merupakan salah satu wujud karya intelektual seseorang yang dilindungi oleh Undang-undang Merek di Indonesia. Merek merupakan tanda yang berupa gambar, nama, kata, huruf, angka-angka, susunan warna, atau kombinasi dari unsur-unsur tersebut sebagai identitas dari suatu produk (meliputi ruang lingkup, atribut, kualitas, dan penggunaan) kepada konsumen yang memiliki daya pembeda, yaitu membedakan sebuah produk barang atau jasa yang dihasilkan pihak yang satu dengan pihak yang lain (kompetitor) dengan kriteriakriteria yang ada di dalamnya. Merek tersebut lama-kelamaan dapat menjadi asset dari suatu perusahaan.

Setelah Indonesia meratifikasi Konvensi tentang Pembentukan Organisasi Perdagangan Dunia atau World Trade Organization (WTO) guna mengesahkan Undang-undang Nomor 7 Tahun 1994 tentang Pengesahan Persetujuan Pembentukan Organisasi Perdagangan Dunia atau Agreement Establishing the WTO, dilakukan pembenahan dalam berbagai peraturan perundang-undangan tentang Hak Kekayaan Intelektual di Indonesia.

Termasuk pula Undang-undang Merek di Indonesia, tepatnya pada tanggal 1 Agustus 2001 mulai diberlakukan Undang-undang Nomor 15 Tahun 2001 tentang Merek yang menggantikan Undang-undang Nomor 14 Tahun 1997 tentang Perubahan atas Undangundang Nomor 19 Tahun 1992 tentang Merek. Perubahan ini bertujuan untuk mengantisipasi perkembangan teknologi informasi dan transportasi yang telah mendukung kegiatan di sektor perdagangan semakin meningkat secara pesat, mempertahankan iklim persaingan usaha yang sehat, serta menampung beberapa aspek dalam Persetujuan TRIPs yang belum dimuat dalam Undang-undan Nomor 14 Tahun 1997 tentang Merek.

Lahirnya Undang-undang Nomor 15 Tahun 2001 tentang Mere memberikan warna baru dalam dunia usaha di Indonesia. Merek menjadi salah satu unsur penting yang dapat mewakili produsen untuk memperkenalkan identitas produknya kepada masyarakat luas. Melalui merek dapat digambarkan kualita masing-masing merek yang dijual. Turutsertanya Indonesia dalam era globalisasi menimbulkan tingkat persaingan yang semakin meninggi. Dalam persaingan usaha yang cukup ketat, timbul banyak kecurangankecurangan yang dilakukan oleh pelaku usaha untuk menjatuhkan kompetitor usahanya, misalnya dengan melakukan pemalsuan merek atau pemakaian merek milik orang lain secara tanpa izin. Hal tersebut dapat menimbulkan kerugian bagi pemilik merek yang sebenarnya apabila kualitas yang dijual tidak sama dengan kualitas yang asli. Selain itu juga menimbulkan kebingungan bagi masyarakat luas.

Undang-undang Merek diciptakan guna mengantisipasi hal-hal tersebut di atas. Namun, agar merek tersebut bisa memperoleh perlindungan hukum harus memenuhi 
persyaratan-persyaratan yang diatur dalam Undang-undang Merek dan peraturanperaturan lain yang mengatur tentang merek.

Merek yang tertera pada kemasan yang dijual di Jalan termasuk merek dagang. Hal ini dikarenakan merek tersebut digunakan dalam rangka memperdagangkan yang dilakukan oleh perseorangan atau beberapa orang secara bersama-sama atau badan hukum. Merek yang tertera pada kemasan yang dijual tersebut menjadi pembeda dari produk-produk lainnya. Pengertian merek dagang diatur dalam Pasal 1 angka 2 Undang-undang Nomor 15 Tahun 200 tentang Merek yang berbunyi sebagai berikut.

Hukum merek Indonesia menganut sistem "first to file", sehingga yang mendaftarkan pertama kali adalah yang berhak atas kepemilikan suatu merek. Agar merek-merek tersebut dapat dilindungi hukum, khususnya hukum merek di Indonesia, maka merek tersebut harus didaftarkan ke Departemen Kehakiman dan Hak Asasi Manusia - Direktorat Jenderal Hak Kekayaan Intelektual sehingga terdaftar dalam Daftar Umum Merek dan pemilik merek yang sebenarnya akan mendapat sertifikat merek sebagai tanda bukti hak/kepemilikan atas merek dagang produk. Bila tidak, maka pemilik merek yang sebenarnya akan sulit membuktikan haknya apabila suatu ketika merek tersebut digunakan pihak lain atau digugat oleh pihak lain. Mengenai hak atas merek tersebut diatur dalam Undang-undang Nomor 15 Tahun 2001 tentang Merek berbunyi sebagai berikut yaitu Hak atas Merek adalah hak ekslusif yang diberikan oleh Negara kepada pemilik Merek yang terdaftar dalam Daftar Umum Merek untuk jangka waktu tertentu dengan menggunakan sendiri Merek tersebut atau memberikan izin kepada pihak lain untuk menggunakannya.

Sertifikat merek merupakan tanda bukti bahwa merek tersebut telah didaftarkan dalam Daftar Umum Merek. Undang-undang Nomor 15 Tahun 2001 tentang Merek memberikan hak ekslusif kepada pemiliknya. Hak ekslusif ini memberikan jaminan perlindungan hukum atas merek yang mereka gunakan. Hak ekslusif ini melarang produsen lain menggunakan merek dengan tulisan ataupun gambar yang sama pada kemasannya.

Hak tersebut tidak diberikan kepada para produsen yang belum memiliki sertifikat merek. Dalam kelanjutan usahanya, merek yang mereka gunakan bisa digunakan oleh orang lain. Undang-undang Nomor 15 Tahun 2001 tentang Merek tidak memberikan perlindungan hukum bagi merek yang belum terdaftar dalam Daftar Umum Merek. Sehingga, produsen yang belum

mendaftarkan mereknya tidak bisa melakukan tindakan hukum atau gugatan kepada pihak ketiga yang memakai merek mereka tanpa izin.

Agar pemilik merek dapat mempunyai sertifikat merek, mereka harus mengajukan permohonan pendaftaran merek kepada Direktorat Jenderal Hak Kekayaan Intelektual (Ditjen HAKI). Syarat dan tatacara 
pendaftaran merek telah diatur dalam Undang-undang Nomor 15 Tahun 2001 tentang Merek, yaitu dalam Pasal 7 sampai dengan Pasal 12. Permohonan pendaftaran merek harus diajukan secara tertulis, diketik dalam bahasa Indonesia pada blangko formulir permohonan yang telah disediakan dan ditandatangani oleh pemohon atau kuasanya dan dibuat dalam rangkap empat.

Berdasarkan Pasal 6 tersebut, maka permohonan pendaftaran merek yang diajukan oleh Sumardi ditolak karena adanya persamaan pada pokoknya atau keseluruhannya dengan merek milik pihak lain yang sudah terdaftar lebih dulu untuk barang dan/atau jasa yang sejenis atau mempunyai persamaan pada pokoknya atau keseluruhannya dengan merek yang sudah terkenal milik pihak lain untuk barang dan/atau jasa yang tidak sejenis sepanjang memenuhi persyaratan tertentu yang ditetapkan dengan peraturan pemerintah.

Produk atau jasa yang bermerek saling lebih dahulu diiklankan dan dijual, walaupun produk atau jasa tersebut secara fisik belum tersedia di pasaran Negara tertentu. Media penyebaran dan periklanan modern menjadi semakin tidak di batasi oleh batas-batas nasional mengingat canggihnya komunikasi teknologi dan frekuensi orang bepergian atau mengadakan perjalanan melintas dunia. pemilik produk atau jasa yang bermerek banyak memanfatkan berbagai event-event yang banyak di tonton orang untuk memasarkan merek mereka sehingga orang yang melihat merasa tertarik untuk membeli produk atau meggunakan jasa dari suatu merek yang diiklankan tersebut.

Ditinjau dari aspek hukum masalah merek menjadi sangat penting, sehubungan dengan persoalan perlu adanya perlindungan hukum dan kepastian hukum bagi pemilik atau pemegang merek dan perlindungan hukum terhadap masyarakat sebagai konsumen atas suatu barang atau jasa yang memakai suatu merek agar tidak terkecoh oleh merek-merek lain, tidak dapat dipungkiri lagi bahwa masalah penggunaan merek terkenal oleh pihak yang tidak berhak, masih banyak terjadi di Indonesia dan kenyataan tersebut benar-benar disadari oleh pemerintah. Hal itu tidak dapat dilepaskan dari sisi historis masyarakat Indonesia yang sejak dahulu adalah masyarakat agraris, sehingga terbiasa segala sesuatunya dikerjakan dan dianggap sebagai milik bersama, bahkan ada anggapan dari para pengusaha rumah industri bahwa merek adalah mempunyai fungsi sosial. Pada satu sisi keadaan tersebut berdampak positif tetapi pada sisi lain justru yang anggapan demikian itu menyebabakan masyarakat kita sering berpikir kurang ekonomis dan kurang inofatif.

Sebagai Negara penandatangan persetujuan umum tentang tarif dan perdagangan (General Agrement On Tarif and Trade) dalam putaran Uruguay (Uruguay Round), Indonesia telah meratifikasi paket persetujuan tersebut dengan UU No. 7 Tahun 1994 tentang Ratifikasi Persetujuan 
Pembentukan Organisasi Perdagangan Dunia (Agrement Establishing The World Trade Orgnization). Sejalan dengan itu maka pemerintah membuat kebijakan baru dengan melakukan perubahan dan penyempurnaan UU No. 19 Tahun 1992 dengan UU No. 14 Tahun 1997 dan diubah dan disempurnakan lagi dengan undang undang No. 15 Tahun 2001. Tujuan dari penyempurnaan tersebut tidak lain adalah mengakomodasikan ketentuan-ketentuan yang sudah menjadi komitmen internasional mengenal Hak atas Kekayaan Intelektual.

\section{PENUTUP}

Didalam perlindungan merek merupakan upaya yang dapat menjamin adanya kepastian hukum, sehingga dapat memberikan perlindungan hukum yang bersangkutan atau yang melakukan tindakan hukum.

Pelaksanaan perlindungan hukum merek berdasarkan Undang-undang Nomor 15 Tahun 2001 tentang Merek, khususnya Pasal 3, yaitu mengenai pemberian hak eksklusif oleh negara kepada pemilik merek yang terdaftar dalam Daftar Umum Merek terhadap produk makanan belum dapat terlaksana dengan efektif.

Bagi mereka yang sudah memiliki sertifikat merek mengatakan bahwa mereka merasa lebih tenang dalam menjalankan usahanya ke depan. Selain itu, dengan adanya sertifikat merek, mereka merasa lebih mudah membuktikan hak atas kepemilikan merek yang mereka gunakan, sehingga dalam usahanya tidak lagi mencemaskan apabila suatu ketika ada yang menggugat merek yang mereka gunakan. Justru bagi mereka, sertifikat merek yang dimiliki bisa dijadikan alat untuk menggugat pihak lain yang dengan tanpa izin memproduksi dan menjual dengan merek yang sama sehingga merugikan konsumen yang sudah menjadi langganan. Sertifikat merek merupakan tanda bukti bahwa merek tersebut telah didaftarkan dalam Daftar Umum Merek.

Undang-undang Nomor 15 Tahun 2001 tentang Merek memberikan hak ekslusif kepada pemiliknya. Hak ekslusif ini memberikan jaminan perlindungan hukum atas merek yang mereka gunakan. Hak ekslusif ini melarang produsen lain menggunakan merek dengan tulisan ataupun gambar yang sama pada kemasannya. Akan tetapi hak tersebut tidak diberikan kepada para produsen yang belum memiliki sertifikat merek. Dalam kelanjutan usahanya, merek yang mereka gunakan bisa digunakan oleh orang lain.

Undang-undang Nomor 15 Tahun 2001 tentang Merek tidak memberikan perlindungan hukum bagi merek yang belum terdaftar dalam Daftar Umum Merek. Sehingga, produsen yang belum mendaftarkan mereknya tidak bias melakukan tindakan hukum atau gugatan kepada pihak ketiga yang memakai merek mereka tanpa izin. 


\section{DAFTAR PUSTAKA}

Andrian Suteti, 2009, Hak Atas Kekayaan Intelektual, Jakarta: PT Sinar Grafika

Budi Agus Riswanto dan M. Syamsudin, 2004, Hak Kekayaan Intelektual dan Budaya Hukum, Jakarta: PT Raja Grafindo Persada.

Budi Maulana Insan, Ridwan Khairandy dan Nur Jihad, 2000, Kapita Selekta Hak Kekayaan Intelektual, Yogyakarta: Pusat Studi Hukum UII.

Ok, Sadikin, 2013, Aspek Hukum Hak Kekayaan Intelektual, Jakarta: PT Raja Grafindo Persada.

Taryana, Soenandar, 2007, Perlindungan Hak Milik Intelektual Di NegaraNegara ASEAN, Jakarta: PT Sinar Grafika.
Undang-undang Nomor 30 Tahun 2000 Tentang Rahasia Dagang, 2003, Sinar Grafika, Jakarta

Undang-undang Nomor 31 Tahun 2000 Tentang Desain Industri, 2003, Sinar Grafika, Jakarta

Undang-undang Nomor 14 Tahun 2001 Tentang Hak Paten, 2003, Sinar Grafika, Jakarta

Undang-undang Nomor 15 Tahun 2001 Tentang Merek, 2003, Sinar Grafika, Jakarta

Undang-undang Nomor 19 Tahun 2002 Tentang Hak Cipta, 2004, Citra Aditya Bakti, Jakarta

Undang-undang Perlindungan Hak Atas Kekayaan Intelektual, 2004, Citra Aditya Bakti, Jakarta. 